\title{
Identification of mercury-resistant Streptomyces isolated from Cyperus ro- tundus L. rhizosphere and molecular cloning of mercury (II) reductase gene
}

\author{
Wahyu Aristyaning Putri ${ }^{1}$, Hanum Mukti Rahayu ${ }^{2}$, Anis Uswatun Khasanah ${ }^{3}$, Langkah Sembiring ${ }^{4}$, Masashi Kawaichi ${ }^{5}$, Yekti \\ Asih Purwestri ${ }^{6,7, *}$ \\ ${ }^{1}$ Biotechnology Laboratory, Department of Tropical Biology, Faculty of Biology, Universitas Gadjah Mada. Jl. Teknika Selatan, Sekip Utara, \\ Bulaksumur Yogyakarta 55281, Indonesia \\ ${ }^{2}$ Program of Biology Education, Faculty of Teacher Training and Education, Universitas Muhammadiyah Pontianak. Jl. Ahmad Yani No. 111 \\ Pontianak 78124, West Kalimantan, Indonesia \\ ${ }^{3}$ Biology Laboratory, Program of Biology, Department of Science, UIN Sultan Maulana Hasanuddin Banten. Jl. Jalan Jendral Sudirman No. \\ 30 Panancangan Cipocok Jaya, Sumurpecung, Kec. Serang, Kota Serang, Banten 42118, Indonesia \\ ${ }^{4}$ Microbiology Laboratory, Department of Tropical Biology, Faculty of Biology, Universitas Gadjah Mada. J. Teknika Selatan, Sekip Utara, \\ Bulaksumur Yogyakarta 55281, Indonesia \\ ${ }^{5}$ Division of Gene Function in Animals, Nara Institute of Science and Technology, Ikoma, 630-0192, Japan \\ ${ }^{6}$ Biochemistry Laboratory, Department of Tropical Biology, Faculty of Biology, Universitas Gadjah Mada. J. Teknika Selatan, Sekip Utara, \\ Bulaksumur Yogyakarta 55281, Indonesia \\ ${ }^{7}$ Research Center for Biotechnology, Universitas Gadjah Mada. Jl. Teknika Selatan, Sekip Utara, Bulaksumur Yogyakarta 55281, Indonesia \\ *Corresponding author: yekti@ugm.ac.id
}

SUBMITTED 20 May 2021 REVISED 16 August 2021 ACCEPTED 02 November 2021

\begin{abstract}
Streptomyces is one of mercury-resistant bacteria which can convert $\mathrm{Hg}^{2+}$ into nontoxic $\mathrm{Hg}^{0}$. This study aimed to identify mercury-resistant Streptomyces present in the Cyperus rotundus rhizosphere from artisanal small-scale gold mining (ASGM) area and clone merA gene to the cloning and expression vectors. Molecular identification was conducted using 16s rRNA gene with the maximum likelihood algorithms. Results revealed that the AS1 and AS2 strains were a group of Streptomyces ardesiacus and the BR28 strain was closed to Brevibacillus agri. The AS2 merA gene was cloned to pMD20 cloning vectors, pGEX-5x-1 and pET-28c expression vectors. The transformation was successfully performed in BL21 and $\mathrm{DH} 5$ a competent cells. The full length of the merA gene was confirmed to be 1,425 bp. This study is the first research on identifying mercury-resistant Streptomyces and cloning the full-length merA gene in Indonesia.
\end{abstract}

KEYWORDS artisanal gold mining, mercuric reductase, 16s rRNA, plasmid vector

\section{Introduction}

Mercury contamination commonly occurs in the artisanal gold mining areas in Indonesia due to gold amalgamation (Krisnayanti et al. 2012). This contamination is a serious environmental problem that adversely affects human health, especially that of gold mining workers (Niane et al. 2019). Chemical and physical methods for removing heavy metals have been studied for many years, but these methods have created new problems, such as the generation of chemical waste, complicated post-processing, and wasteful costs (Alotaibi et al. 2021). Bioremediation strategies using plants (phytoremediation) and microorganisms have been developed as attractive alternatives because they are effective, inexpensive, and efficient (Tiodar et al. 2021).

Streptomyces are fungi-like appearance bacteria, usually living on the soil or plant rhizosphere. Streptomyces produce important metabolites such as antibacterial, special enzyme and protein. However, reportedly mercuryresistant bacteria were Firmicutes, Planctomycetes, Bacillus, Gammaproteobacteria, Brevundimonas, Nitrococcus, Fusobacterium, Stenotrophomonas, Arthrobacter, Bacillus and Pseudomonas (Purkan et al. 2017; Chasanah et al. 2018; Niane et al. 2019; Fatimawali et al. 2020; Singh and Kumar 2020). On the other hand, Streptomyces was a potential bacteria on mercury transformation due to producing high activity of mercuric reductase enzyme, but rarely explored (Rahayu et al. 2021).

Streptomyces was reported to reduce mercury ions $\left(\mathrm{Hg}^{1+}, \mathrm{Hg}^{2+}\right)$ into elemental mercury $\left(\mathrm{Hg}^{\circ}\right)$ because of their mer operon system located in the linear plasmid (Boyd and Barkay 2012), genomic DNA (Xiao-xi et al. 2010), and Tn21 transposons or integrons (Liebert et al. 1999). The mer operon is a positive type of operon that 
is immensely conserved. It consists of the operator gene; promoter gene; regulatory gene (merR); and functional genes, including merT, merP, $\operatorname{mer} D$, merF, $\operatorname{mer} C$, merA, and merB in broad range of operons (Singh and Kumar 2020). These genes code for a particular protein and execute a particular function in mercury-resistant bacteria.

The cloning of the merA gene from Streptomyces coelicolor M130 was first reported by Hopwood (Hopwood 1983). This technology will presumably reduce mercury contaminants in the soil through cell bioaugmentation processes. Cell bioaugmentation is based on the survival and catabolic activity of inoculated microbial strains (Mosa et al. 2016). The inoculation of bacteria harboring the necessary metabolic pathways for the degradation of target contaminants accelerate the removal of contaminants and reduces the time required for the intended bioremediation (Tiodar et al. 2021).

A previous study explored Streptomyces in the rhizosphere of nutgrass around a traditional small-scale gold mining area in Lombok, Indonesia (Rahayu et al. 2021). In that study, Streptomyces spp. were isolated, and four isolates were categorized as mercuric-resistant strains (Rahayu et al. 2021). However, studies on identifying mercury-resistant Streptomyces and genes involved in mercury bioremediation are still limited, especially in Indonesia. This research was performed to identify mercuryresistant Streptomyces and clone the mercury reductase gene in pMD20 cloning vector, pGEX-5x-1 and pET-28c expression vectors.

\section{Materials and Methods}

\subsection{Subculture of Streptomyces}

Mercury-resistant Streptomyces isolates of strains AS1, AS2, and BR28 from Cyperus rotundus rhizosphere around traditional gold mining in Selodong Hamlet, Buwun Mas Village, Sekotong District, West Lombok, Indonesia (Rahayu et al. 2021) were grown in a yeast extract malt agar (YEMA) with nystatin. The grown isolates were purified using starch nitrate agar (SNA). The isolates obtained were then cultured in slanted SNA and stored at room temperature for the next experiments.

\subsection{Mercury resistance ability test}

The Mercury resistance test was conducted using the paper disk method. Exactly $0.1 \mathrm{~mL}$ of spore suspension was inoculated in SNA using the surface plate method. As much 2, 4, and $6 \mu \mathrm{L}$ of $\mathrm{HgCl}_{2} \mathrm{I} \mathrm{mM}$ was put on the $6 \mathrm{~mm}$ diameter paper disk in the SNA medium, incubated at room temperature for seven days. Strain with less than $1 \mathrm{~cm}$ clear zone diameter was categorized as a resistant strain.

\subsection{Genome isolation and identification based on $16 \mathrm{~s}$ rRNA gene}

Chromosomal DNA isolation was performed using the spooling with a glass rod according to the method (Hopwood 1983) with modifications. The isolation of the $16 \mathrm{~s}$
rRNA gene was performed using the PCR method with general primers 16sF (EC F 5' TCTGCAGTCGACGATGACCAC) and 16sR (EC R3' GTGCCAGCAGCCGCGGTAATA). This gene was amplified using $0.5 \mu \mathrm{L}$ Ex Taq, $25 \mu \mathrm{L} 2 \times$ buffer I, $8 \mu \mathrm{L}$ dNTP mix, $1 \mu \mathrm{L}$ (10 ng) DNA template, $0.5 \mu \mathrm{L}$ Primer F (100 pmol $/ \mu \mathrm{L}), 0.5 \mu \mathrm{L}$ Primer $\mathrm{R}(100 \mathrm{pmol} / \mu \mathrm{L})$, and water until the volume reached 50 $\mu \mathrm{L}(100 \mathrm{pmol} / \mu \mathrm{L})$. The PCR program was run at $94^{\circ} \mathrm{C}$ for $1 \mathrm{~min},\left(94^{\circ} \mathrm{C}\right.$ for $30 \mathrm{~s}, 60^{\circ} \mathrm{C}$ for $30 \mathrm{~s}, 72^{\circ} \mathrm{C}$ for $2 \mathrm{~min}$ ) for 30 cycles, and $72{ }^{\circ} \mathrm{C}$ for $5 \mathrm{~min}$. The PCR products were purified using the column spin method (Geneaid and MD Bio) and sequenced using the PT. Genetika Sain service.

The 16S rRNA sequences were aligned using ClustalW software (Thompson et al. 1994). Type strains references were downloaded from www.ezbiocloud.net based on preliminary checking. The evolutionary trees for the datasets were inferred from the maximum likelihood method based on the Tamura-Nei model using MEGA X (Kumar et al. 2018). The initial tree(s) for the heuristic search were obtained automatically by applying the neighbor-joining and BioNJ algorithms. The topology with a superior log likelihood value was finally selected with the 1,000 resamplings (bootstrap values).

\subsection{Isolation and purification of merA gene}

The merA primer was constructed by ClustalW analysis. The gene isolation was performed by PCR using a specific primer (Table 1 ). The PCR mixture contained $0.5 \mu \mathrm{L} \mathrm{LA}$ Taq, $25 \mu \mathrm{L} 2 \times$ GC buffer I, $8 \mu \mathrm{L}$ dNTP mix, $1 \mu \mathrm{L}$ (10 ng) DNA template, $0.5 \mu \mathrm{L}$ Primer F $(100 \mathrm{pmol} / \mu \mathrm{L}), 0.5 \mu \mathrm{L}$ Primer R (100 pmol/ $\mu \mathrm{L})$, water until a volume of $50 \mu \mathrm{L}$ was reached $(100 \mathrm{pmol} / \mu \mathrm{L})$. The PCR program was run at $94{ }^{\circ} \mathrm{C}$ for $1 \mathrm{~min},\left(94^{\circ} \mathrm{C}\right.$ for $30 \mathrm{~s}, 60^{\circ} \mathrm{C}$ for $30 \mathrm{~s}, 72{ }^{\circ} \mathrm{C}$ for $2 \mathrm{~min}$ ) for 25 cycles, and $72^{\circ} \mathrm{C}$ for $5 \mathrm{~min}$. Purification was conducted by the glass powder method (Marko et al. 1982).

\subsection{Cloning to the vector}

The cloning vector used in this work was pMD20. The ligation of merA gene to the cloning vector was performed by mixing $3 \mu \mathrm{L} \mathrm{10 \times} \mathrm{T4} \mathrm{ligase} \mathrm{buffer,} 3 \mu \mathrm{L} 10 \mathrm{mM}$ ATP, $0.6 \mu \mathrm{L}$ T-vector pMD20 (2.7 kB, $30 \mathrm{ng}$ ), $3 \mu \mathrm{L}$ insert (merA gene $1.4 \mathrm{kB}, 45 \mathrm{ng}$ ), $0.5 \mu \mathrm{L}$ T4 ligase, and water up to 30 $\mu \mathrm{L}$. The mixture was incubated at $16{ }^{\circ} \mathrm{C}$ overnight.

The expression vectors used in this work were pGEX$5 x-1$ and pET-28c. The mixture contained $10 \times$ buffer, $3 \mu \mathrm{g}$ DNA, $10 \mathrm{U} / \mu \mathrm{L}$ restriction enzyme, and water. The mixture was then incubated at $37^{\circ} \mathrm{C}$ for one $\mathrm{h}$ and subjected to agarose gel electrophoresis. DNA was purified using the glass powder method. The C-terminal, N-terminal, and vector were ligated. The ligation mixture contained $3 \mu \mathrm{L} 10 \times$ ligase buffer, $3 \mu \mathrm{L} 10 \mathrm{mM}$ ATP, $1 \mu \mathrm{L}$ vector (30 $\mathrm{ng} / \mu \mathrm{L}), 3 \mu \mathrm{L}$ N-terminal gene $(2 \mathrm{ng} / \mu \mathrm{L}), 4 \mu \mathrm{L}$ C-terminal gene ( $5 \mathrm{ng} / \mu \mathrm{L}), 0.5 \mu \mathrm{L}$ T4 ligase, and water up to $30 \mu \mathrm{L}$. The mixture was incubated at $16{ }^{\circ} \mathrm{C}$ overnight and transformed into competent cells BL21. 
TABLE 1 Sequences of merA primer

\begin{tabular}{|c|c|c|c|}
\hline Primer & Sequence & Strain & Resource \\
\hline merAF1-BamH1 & ATA /GGA TCC/ CCG GTT ACG ATC TGG CG & AS1 and AS2 & ClustalW analysis \\
\hline merAR1-Xho1 & ATA /CTC GAG/ TCA GCC GGC GCA GCA GGA & AS1 and AS2 & ClustalW analysis \\
\hline StrMerA-F2 & ACT ACC TGA CCT CCA CCA G & AS1 and AS2 & ClustalW analysis \\
\hline Act-Fw & CGG ACT TCG TST ACG TCG C & BR28 & $\begin{array}{l}\text { (Oregaard and } \\
\text { Sørensen 2007) }\end{array}$ \\
\hline Act-Rv & GCC ATG AGG TAS GGG & BR28 & $\begin{array}{l}\text { (Oregaard and } \\
\text { Sørensen 2007) }\end{array}$ \\
\hline Slivid-5Up-F & ACT GAG GGA GGT AGT GCT & $\mathrm{N}$-terminal of merA AS1, AS2 & ClustalW analysis \\
\hline AS2-RV-Pst1 & TCA GCG CGA CCT GCA GGA CG & $\mathrm{N}$-terminal of merA AS2 & ClustalW analysis \\
\hline AS1-RV Nrul & CGG /TCG CGA/ TGA CGT AGT G & N-terminal of merA AS1 & ClustalW analysis \\
\hline AS2-Ini BamHI & TAT /GGA TCC/ TGC TCC AGG CAC ACA CC & $\mathrm{N}$-terminal of merA AS1, AS2 & ClustalW analysis \\
\hline
\end{tabular}

\subsection{Transformation to E. coli BL21 and DH5a}

As much as $3 \mu \mathrm{L}$ of ligation mixture was transferred to $200 \mu \mathrm{L}$ competent cells (BL21 and DH5 $\alpha$ ) by heat shock method (Anggoro and Ratnaningsih 2018). Thereafter, $100 \mu \mathrm{L}$ of the mixture was placed in $900 \mu \mathrm{L} \mathrm{LB}$ agar with ampicillin (for pMD20 and pGEX-5x-1) and kanamycin (for pET-28c). Positive colonies were picked and inoculated into LB with kanamycin (for pET-28c) and ampicillin (for pMD20 and pGEX-5x-1). After overnight incubation at $37^{\circ} \mathrm{C}$, the plasmid was isolated using the alkaline lysis method.

\subsection{Transformant confirmation and sequencing}

The plasmid transformant was confirmed using the enzyme digestion method. As much as $2 \mu \mathrm{L}$ of plasmid was added with the digestion mixture $(1 \mu \mathrm{L} 10 \times \mathrm{K}$ buffer, 0.3 $\mu \mathrm{L}$ XhoI, $0.3 \mu \mathrm{L}$ PstI or BamHI, and $6.4 \mu \mathrm{L}$ water). The mixture was incubated at $37^{\circ} \mathrm{C}$ for $1 \mathrm{~h}$, added with $1 \mu \mathrm{L}$ loading dye solution, and then subjected to agarose gel electrophoresis. The digestion enzyme was modified on the basis of the restriction site in each vector. Confirmation was also performed by sequencing procedures using BigDye version 1 or 3.

\section{Results and Discussion}

\subsection{Mercury resistance ability test}

Mercury-resistant Streptomyces isolates consisting of strains AS1, AS2, and BR28 from liquid glycerol medium and slant culture were grown back in a YEMA plate medium with nystatin to prevent contamination from mold. Streptomyces are members of the gram-positive group of bacteria that can only grow on a medium with a source of complex carbohydrates, such as SNA. The medium is acidified at a $\mathrm{pH}$ of 5 to maintain the solubility of mercury (Figure 1a). In this study, $1 \mathrm{mM}$ of $\mathrm{HgCl}_{2}$ was added to the filter paper. The clear zone less than 10 $\mathrm{mm}$ in the growth of Streptomyces on the SNA medium implied the resistance of Streptomyces to mercury (Figure 1b) (Table 2).

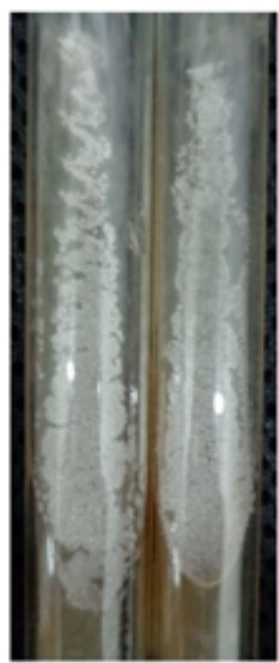

(AS1)

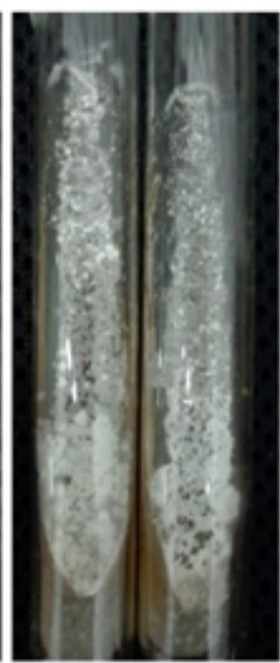

(AS2)

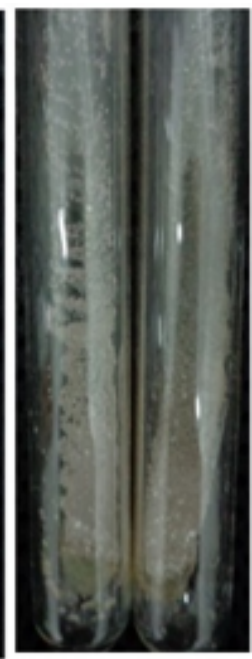

(BR28) (a)

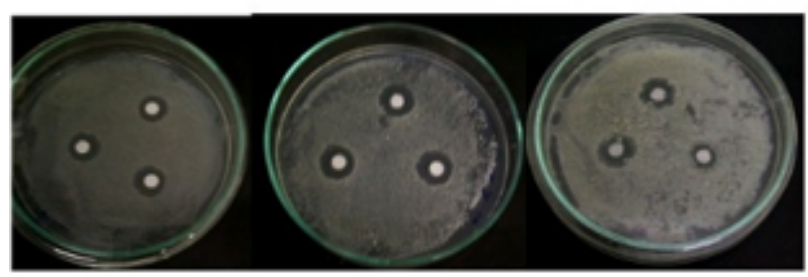

(AS1)

(AS2)

(BR28)

(b)

FIGURE 1 (a) Strain's colony in the SNA medium. (b) Mercuryresistant ability test using paper disk method.

\subsection{Genome isolation and identification based on $16 \mathrm{~s}$ rRNA gene}

Chromosomal DNA isolation is shown in Figure 2a. This study successfully isolated the $16 \mathrm{~s}$ rRNA gene with a length of 1,504 bp by using a universal 16 s primer (Figure 2b). As a molecular marker, 16s rRNA is the conserved gene that shows the phylogenetic relationship among prokaryotes. Herein, the sequences of these genes were compared with the 16s rRNA genes from GenBank. 
TABLE 2 Diameter of clear zone

\begin{tabular}{lccc}
\hline \multirow{2}{*}{ Isolates } & \multicolumn{3}{c}{ Volume of $1 \mathrm{mM} \mathrm{HgCl}_{2}(\mu \mathrm{L})$} \\
\cline { 2 - 4 } & 2 & 4 & 6 \\
\hline AS1 & $7.000 \pm 0.000$ & $13.667 \pm 0.577$ & $16.667 \pm 0.577$ \\
AS2 & $9.667 \pm 0.577$ & $13.667 \pm 0.577$ & $17.333 \pm 0.577$ \\
BR28 & $9.333 \pm 0.577$ & $10.333 \pm 0.577$ & $15.000 \pm 0.000$ \\
\hline
\end{tabular}

Diameter is in $\mathrm{mm} \pm \mathrm{SD}$

Replication was three times for each group

The complete sequences were analyzed and constructed using the phylogenetic analyzer of the MEGA X program (Kumar et al. 2001) (Figure 3). Based on the MCL analysis (Santorum et al. 2014) of the 16s rRNA gene, AS1 and AS2 were identified to be close to $S$. ardesiacus. This result was supported by the bootstrap value of $99 \%$ between AS1 and AS2 and S. ardesiacus. Surprisingly, BR28 was deemed close to Brevibacillus agri. The complete sequences of the 16S rRNA gene of strains AS1 and AS2 have been deposited in the DNA Data Bank of Japan (DDBJ), with accession numbers LC026159 and LC026160 for AS1 and AS2, respectively. The BR28 sequence is in the process of being submitted to GenBank.

The evolutionary history was inferred using the Maximum Likelihood method and Tamura-Nei model. The bootstrap consensus tree inferred from 1000 replicates was taken to represent the evolutionary history of the taxa analyzed. Branches corresponding to partitions reproduced in less than $50 \%$ bootstrap replicates were collapsed. Initial tree(s) for the heuristic search were obtained automatically by applying Neighbor-Join and BioNJ algorithms to a matrix of pairwise distances estimated using the TamuraNei model, and then selecting the topology with a superior log-likelihood value. This analysis involved 31 nucleotide sequences. Codon positions included were 1st+2nd+3rd+Noncoding. There were a total of 1868 positions in the final dataset. Evolutionary analyses were conducted in MEGA X.

\section{3. merA gene isolation}

The merA gene was isolated from chromosomal DNA. However, obtained merA genes were not shown in specific bands (Figure 2c.); therefore, merA were purified using the glass powder method, checked with sequencing to gain the single band and correct merA full gene.

\subsection{Cloning to the vectors}

The cloning on the pMD20 vector results was confirmed by the restriction method. The merA gene showed a length of around 1,400 bp when the vector showed a length of 5.1 $\mathrm{kbp}$. The complete sequences (1,425 bp) of the merA gene of AS2 have been deposited in the DDBJ with accession numbers LC026157 and LC026158. The merA gene of AS1 and BR28 has not been successfully sequenced yet.

The selected expression vector must be adjusted to the open reading frame of the cloned gene (merA). An error in the selection of expression vectors can cause changes

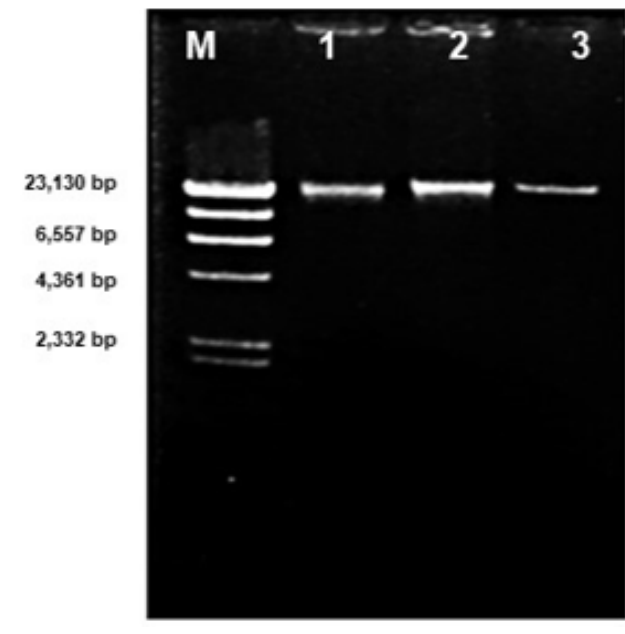

(a)

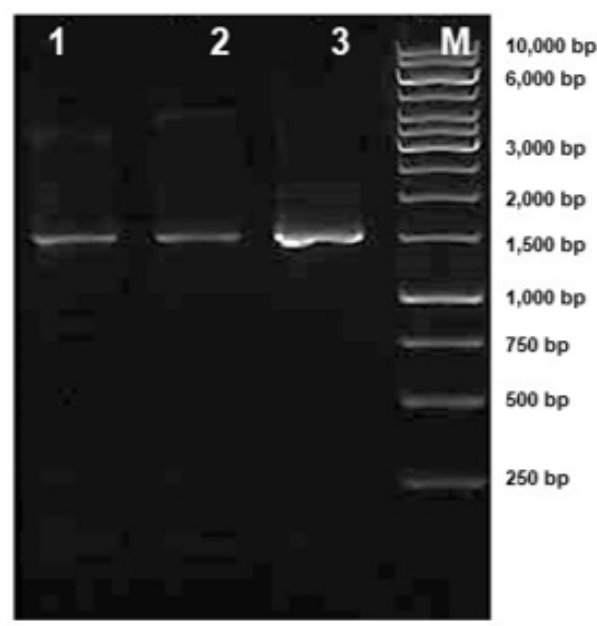

(b)

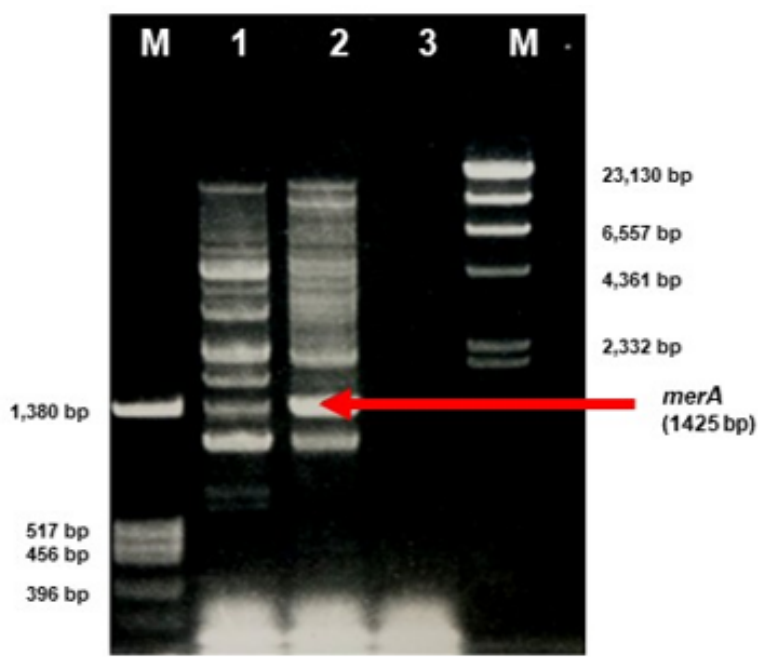

(c)

FIGURE 2 (a) Chromosomal DNA isolated using spooling with a glass rod, M: marker $\lambda /$ HindIII, 1: Streptomyces isolate AS1, 2: Streptomyces isolate AS2, 3: Streptomyces isolate BR28. (b) 16s rRNA gene. (c) merA gene, M: marker BSM 13 and marker $\lambda$ /HindIII.

in the open reading frame protein expressed. As shown in Figure 4a., the pET-28c vector cut with BamHI and XhoI presents the correct cutting edge. Figure $4 \mathrm{~b}$. shows the 


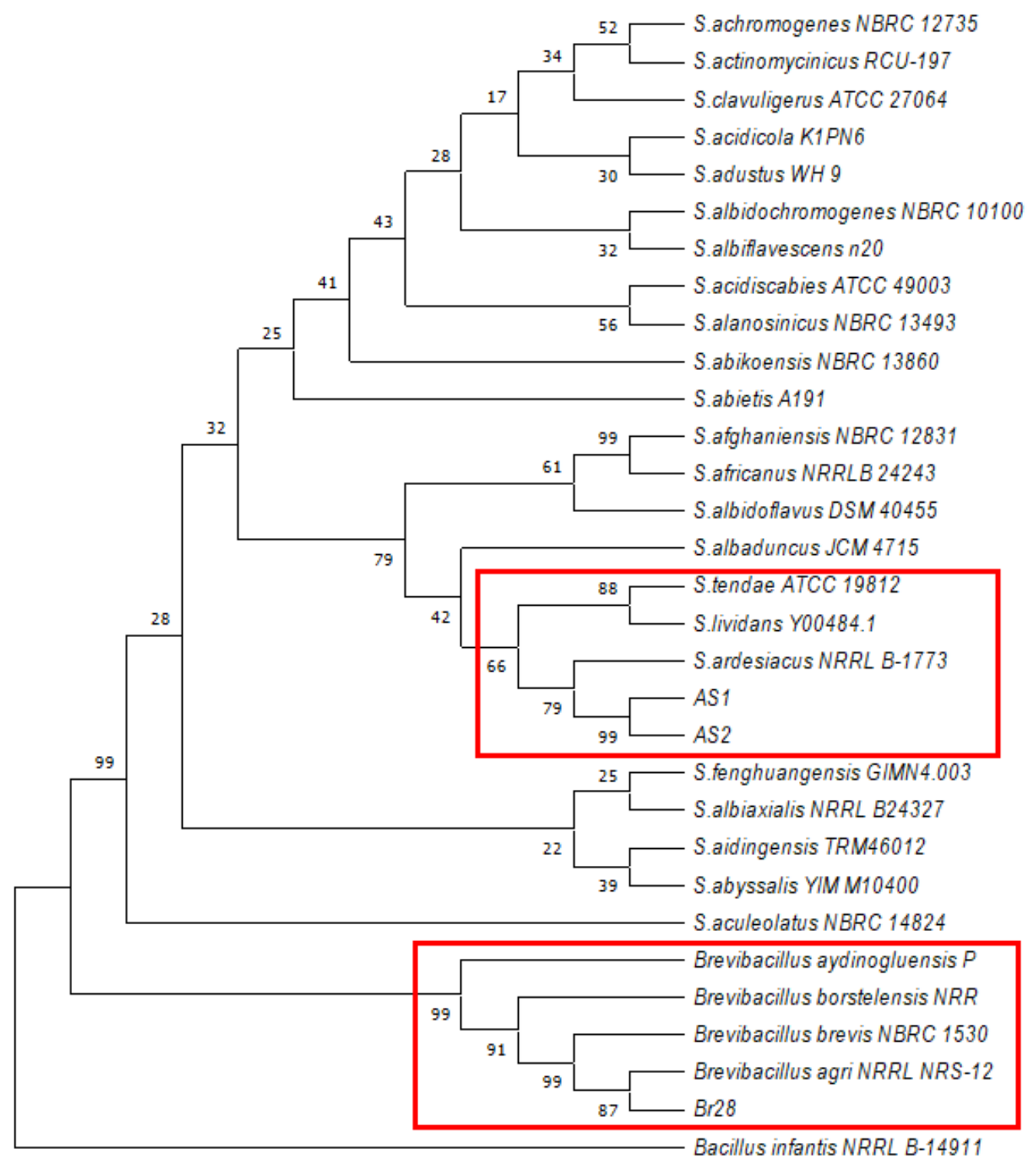

FIGURE 3 Molecular phylogenetic analysis by maximum likelihood method

results of the enzyme cut appropriately to vector length (5.4 kb). The length of the merA gene from PstI to XhoI was approximately $1.1 \mathrm{~kb}$. As shown in Figures $4 \mathrm{a}$ and $4 \mathrm{~b}$, the insertion of the merA gene into the vector pET-28c was correct. Figure $4 \mathrm{c}$ shows the results of cutting the pGEX$5 \mathrm{x}-1$ plasmid using restriction enzymes. The vector length $(4.9 \mathrm{~kb})$ and the length of the merA gene from BamHI to XhoI were equal to $1.4 \mathrm{~kb}$. Cutting using BamHI, PstI, and XhoI produced 3 bands: vector $4.9 \mathrm{~kb}, 0.4 \mathrm{~kb}$ from BamHI to PstI, and $1.1 \mathrm{~kb}$ from PstI to XhoI. This result showed that the merA gene was successfully cloned into an expression vector with the correct restriction site.

\subsection{Discussion}

This study described the mercury-resistant Streptomyces present in the Cyperus rotundus rhizosphere in the artisanal small-scale gold mining area in Lombok, Indonesia. Association between Streptomyces and nutgrass root sys- tem emergence the ability to face environmental stress due to mercury contamination. In situ mercury-bioremediation using indigenous microorganisms was reported for the first time in Indonesia (Winardi et al. 2020). However, identification of the microbes was not conducted. Identification of indigenous mercury-resistant bacteria is essential for effective bioremediation processes. Our study reported that S. ardesiacus AS1, S. ardesiacus AS2 and B. agri BR28 were mercury-resistant bacteria with potential for mercury transformation. These findings will enrich the information about mercury-resistant bacteria, especially from Indonesia whereas Bacillus, Brevundimonas, Klebsiella, Pseudomonas, and Nitrococcus, reportedly in the previous studies (Fatimawali et al. 2014; Zulaika and Sembiring 2015; Chasanah et al. 2018; Imron et al. 2019; Fatimawali et al. 2020).

The presence of indigenous bacteria is important for microorganism-assisted bioremediation in certain areas. 


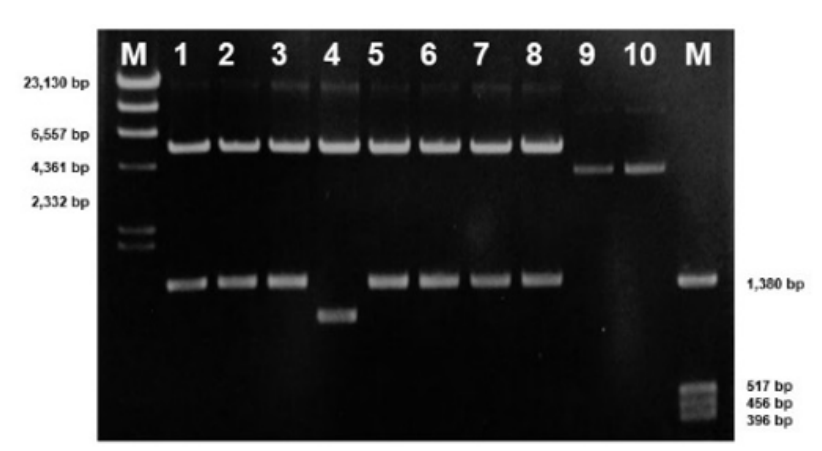

(a)

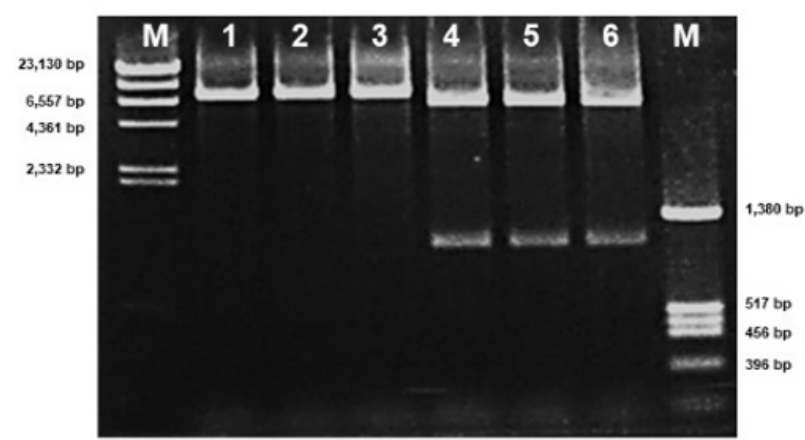

(b)

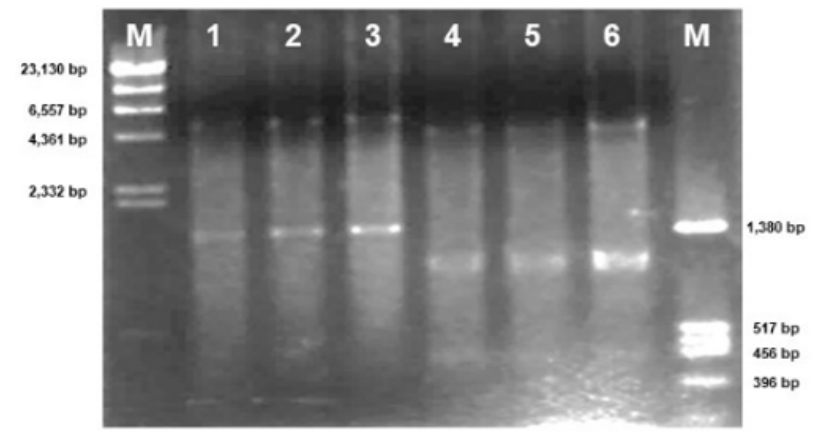

(c)

FIGURE 4 (a) pET-28c vector with merA restricted using BamHI and Xhol, M: marker $\lambda /$ HindIII, 1-8: transformant plasmid cut only with $\mathrm{BamHI}$ and Xhol, 9-10: transformant plasmid not inserted with merA, M2: marker BSM 13. (b) pET-28c vector with merA restricted using Pstl and Xhol, M: marker $\lambda /$ HindIII, 1-3: transformant plasmid cut only with Pstl, 4-6: transformant plasmid cut using Pstl and Xhol, M2: marker BSM 13. (c) Restriction sites on pGEX-5x1 with merA inserted, $M$ : marker $\lambda /$ HindIII, 1-3: plasmids cut with BamHI and Xhol, 4-6: plasmids cut using BamHI, Pstl, and Xhol, M2: marker BSM 13

Naturally, indigenous mercury-resistant bacteria will be more adaptive to climate and environmental conditions, resulting in more effective and efficient mercury biodegradation processes. Interestingly, the mercuric reductase is the key enzyme of mercury volatilization. This enzyme plays a role in reducing ionic mercury into a volatile form (Singh and Kumar 2020). This enzyme is encoded by merA gene, which is found in most mercury-resistant microorganisms.

Cloning of merA is essential to reveal how these genes work. Our study was successfully cloned using multiple primer sets and confirmed that the length of the merA gene is $1,425 \mathrm{bp}$ and encoded as $474 \mathrm{aa}$. This finding was differ- ent from Fatimawali's merA study isolated from Klebsiella pneumoniae. The merA partial gene was successfully obtained 285 bp length, which encoded 94 aa due to using a single primer set (Fatimawali et al. 2014). Using multiple primer sets was recommended to obtain a full sequence of merA genes.

Recently, Zhang et al. (2021) developed an artificial mer operon which could detect, quantify and remove bioavailable heavy metal ions. In the future, gene cloning is predicted to be an important tool to develop biosensors, a suitable synthetic biological device to identify, detect and eliminate the bioavailable part of the environmental mercury or other heavy metal.

\section{Conclusions}

Based on the phylogenetic analysis of 16S rRNA gene sequences, the Streptomyces present in the rhizosphere of Cyperus rotundus in this study was classified into S. ardesiacus. Moreover, the full sequences of merA genes were successfully cloned in the cloning and expression vector with a confirmation length of 1,425 bp. Further cohort studies are needed to obtain recombinant protein expression in E. coli.

\section{Acknowledgments}

This research was partly funded by the Faculty of Biology, BOPTN Grand research funding contract number UGM/BI/2408/M/05/01 to YAP. We thank NAIST Japan for supporting WAP for doing research at NAIST by the Special Research Student Program, Joint Program NAIST and Universitas Gadjah Mada.

\section{Authors' contributions}

WAP designed and performed the experiments and wrote the manuscript; HMR analyzed the data, AUK analyzed the data; and LS, MK, and YAP designed the experiments. All authors read and approved the final version of the manuscript.

\section{Competing interests}

The authors declare no conflict of interest in this research.

\section{References}

Alotaibi BS, Khan M, Shamim S. 2021. Unraveling the underlying heavy metal detoxification mechanisms of bacillus species. Microorganisms 9(8):1628. doi:10.3390/microorganisms9081628.

Anggoro RR, Ratnaningsih E. 2018. Expression of haloacid dehalogenase gene and its molecular protein characterization from Klebsiella pneumonia ITB1. Indones J Biotechnol. 22(1):1. doi:10.22146/ijbiotech.26004. 
Boyd ES, Barkay T. 2012. The mercury resistance operon : from an origin in a geothermal environment to an efficient detoxification machine. Frontiers in Microbiology 3(October):1-13. doi:10.3389/fmicb.2012.00349.

Chasanah U, Nuraini Y, Handayanto E. 2018. The potential of mercury-resistant bacteria isolated from small-scale gold mine tailings for accumulation of mercury. J. Ecol. Eng. 19(2):236-245. doi:10.12911/22998993/83565.

Fatimawali, Kepel BJ, Gani MA, Tallei TE. 2020. Comparison of Bacterial Community Structure and Diversity in Traditional Gold Mining Waste Disposal Site and Rice Field by Using a Metabarcoding Approach. Int. J. Microbiol. 2020. doi:10.1155/2020/1858732.

Fatimawali F, Kepel B, Yusuf I, Badaruddin F, Natsir R, Retnoningrum D. 2014. Isolation and Characterization of Partial Sequence of merA Gene from Mercury Resistant Bacterium Klebsiella pneumonia Isolated from Sario River Estuary Manado. Res. J. Environ. Earth Sci. 6(3):156-160. doi:10.19026/rjees.6.5754.

Hopwood D. 1983. Cloning and Expression of the Tyrosinase Gene from Streptomyces antibioticus i n Streptomyces lividans. Journal of General Microbiology 129:2703-2714. doi:10.1099/00221287-129-9-2703.

Imron MF, Kurniawan SB, Soegianto A. 2019. Characterization of mercury-reducing potential bacteria isolated from Keputih non-active sanitary landfill leachate, Surabaya, Indonesia under different saline conditions. J. Environ. Manage. 241:113-122. doi:10.1016/j.jenvman.2019.04.017.

Krisnayanti BD, Anderson CWN, Utomo H, Feng X. 2012. Assessment of environmental mercury discharge at a four-year-old artisanal gold mining area on Lombok Island, Indonesia. Journal of Environmental Monitoring 14:2598-2607. doi:10.1039/c2em30515a.

Kumar S, Stecher G, Li M, Knyaz C, Tamura K. 2018. MEGA X: Molecular evolutionary genetics analysis across computing platforms. Mol Biol Evol. 35(6):1547-1549. doi:10.1093/molbev/msy096.

Kumar S, Tamura K, Jakobsen IB, Nei M. 2001. MEGA2: molecular evolutionarygenetics analysis software. Bioinformatics applications note 17(12):1244-1245. doi:10.1093/bioinformatics/ 17.12.1244.

Liebert CA, Hall RM, Summers AO. 1999. Transposon Tn 21 , Flagship of the Floating Genome. American Society for Microbiology 63(3):507-522. doi:10.1128/MMBR.63.3.507-522.1999.

Marko MA, Chipperfield R, Birnboim HC. 1982. A procedure for the large-scale isolation of highly purified plasmid DNA using alkaline extraction and binding to glass powder. Anal. Biochem. 121(2):382-387. doi:10.1016/0003-2697(82)90497-3.

Mosa KA, Saadoun I, Kumar K, Helmy M. 2016. Potential Biotechnological Strategies for the Cleanup of Heavy Metals and Metalloids. Frontiers in Plant Science 7(March):1-14. doi:10.3389/fpls.2016.00303.
Niane B, Devarajan N, Pote. 2019. Quantification and characterization of mercury resistant bacteria in sediments contaminated by artisanal small-scale gold mining activities, Kedougou region, Senegal. J Geochemical Explor. 205(8):0375-6742. doi:10.1016/j.gexplo.2019.106353.

Oregaard G, Sørensen SJ. 2007. High diversity of bacterial mercuric reductase genes from surface and subsurface floodplain soil (Oak Ridge, USA). ISME J. 1(5):453-467. doi:10.1038/ismej.2007.56.

Purkan P, Nuzulla YF, Hadi S, Prasetyawati ET. 2017. Biochemical Properties of Mercuric Reductase from Local Isolate of Bacillus sp for Bioremediation Agent. Molekul 12(2):182-188. doi:10.20884/1.jm.2017.12.2.398.

Rahayu HM, Putri WA, Khasanah AU, Sembiring L, Purwestri YA. 2021. Indigeneous streptomyces spp. Isolated from cyperus rotundus rhizosphere indicate high mercuric reductase activity as a potetial bioremediation agent. Biodiversitas 22(3):1519-1525. doi:10.13057/biodiv/d220357.

Santorum JM, Darriba D, Taboada GL, Posada D. 2014. Jmodeltest.org: Selection of nucleotide substitution models on the cloud. Bioinformatics 30(9):1310 1311. doi:10.1093/bioinformatics/btu032.

Singh S, Kumar V. 2020. Mercury detoxification by absorption, mercuric ion reductase, and exopolysaccharides: a comprehensive study. Environ Sci Pollut Res. 27(22):27181-27201. doi:10.1007/s11356-01904974-w.

Thompson JD, Higgins DG, Gibson TJ. 1994. CLUSTAL $\mathrm{W}$ : improving the sensitivity of progressive multiple sequence alignment through sequence weighting , position-specific gap penalties and weight matrix choice. Nucleic Acids Research 22(22):4673-4680. doi:10.1093/nar/22.22.4673.

Tiodar E, Vacar CL, Podar D. 2021. Phytoremediation and microorganisms-assisted phytoremediation of mercury-contaminated soils: Challenges and perspectives. Int J Environ Res Public Health 5(5):1-38. doi:10.3390/ijerph18052435.

Winardi W, Haryono E, Sudrajat S, Soetarto ES. 2020. In situ bioremediation strategies for the recovery of mercury- contaminated land in abandoned traditional gold mines in Indonesia. Biosaintifika 12(3):469 477. doi:10.15294/biosaintifika.v12i3.25229.

Xiao-xi Z, Jian-xin T, Pei J. 2010. Isolation, characterization and extraction of mer gene of $\mathrm{Hg} 2+$ resisting strain D2. Transaction of nNonferrous Metals Society of China 20:507-512. doi:10.1016/S10036326(09)60170-9.

Zhang NX, Guo Y, Li H, Yang XQ, Gao CX, Hui CY. 2021. Versatile artificial mer operons in Escherichia coli towards whole cell biosensing and adsorption of mercury. PLoS One 16(5 May). doi:10.1371/journal.pone.0252190.

Zulaika E, Sembiring L. 2015. Mercury reductase activity of an indigenous mercury resistant bacterial isolate 
(Bacillus sp. S1) from Kalimas-Surabaya as a potential reducing agent for mercurial ion $(\mathrm{Hg} 2+)$. KnE Life Sci. 2(1):446. doi:10.18502/kls.v2i1.190. 